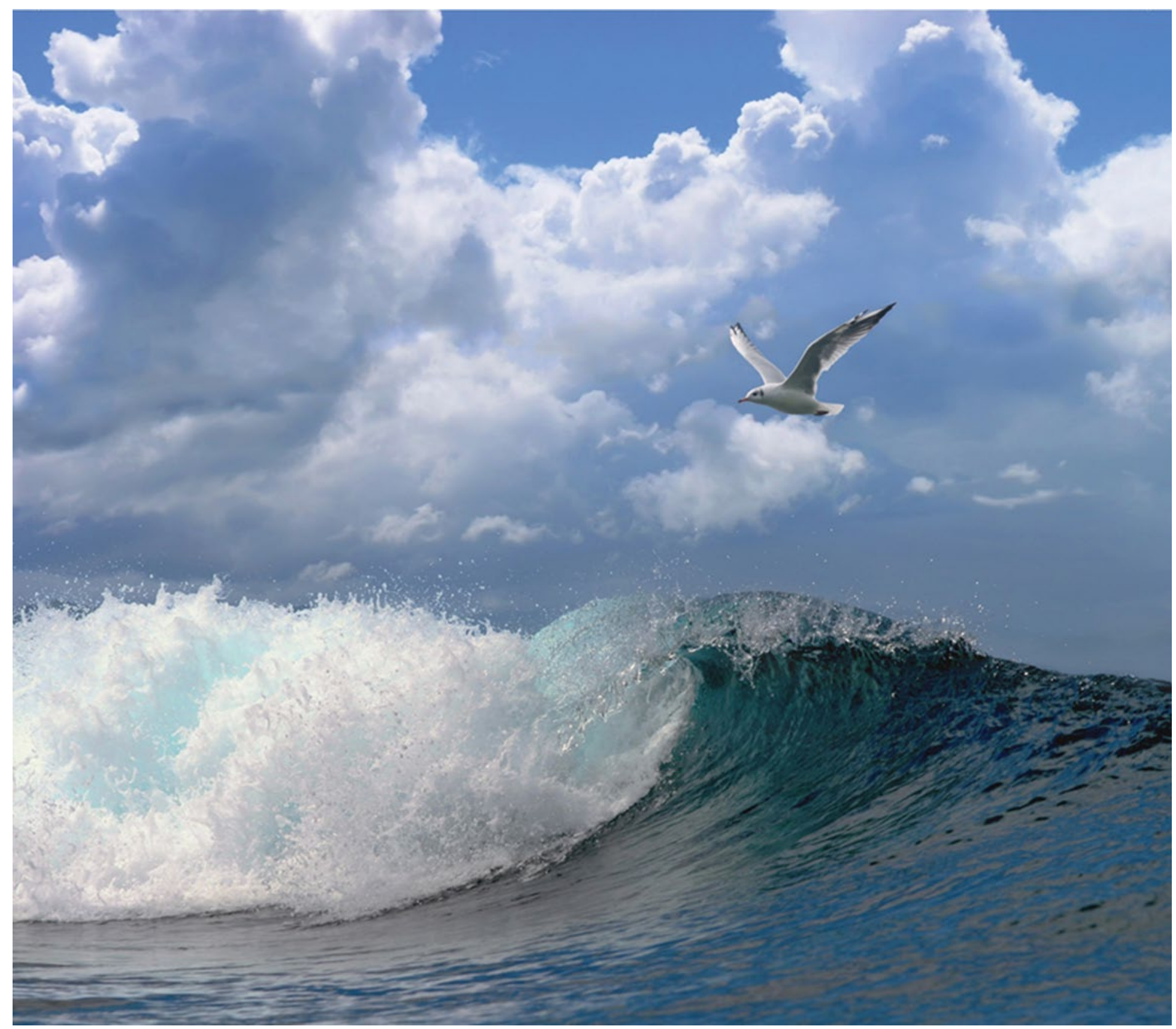

\title{
Aalonderzoek Hoogheemraadschap van Delfland: groei en verspreiding van rode aal (Anguilla anguilla) 2019
}




\section{Aalonderzoek Hoogheemraadschap van Delfland: groei en verspreiding van rode aal (Anguilla anguilla) 2019}

Auteur(s):

A.B. Griffioen

Wageningen Marine Research

IJmuiden, december 2019

Wageningen Marine Research rapport C131/19 
Keywords: Rode aal, groeisnelheid, verspreiding, Delfland, PIT-tag

Opdrachtgever: Hoogheemraadschap van Delfland

t.a.v. W. van der Ende

Postbus 3061

2601 DB Delft

Dit rapport is gratis te downloaden van https://doi.org/10.18174/509538

Wageningen Marine Research verstrekt geen gedrukte exemplaren van rapporten.

Wageningen Marine Research is ISO 9001:2015 gecertificeerd.

(c) 2018 Wageningen Marine Research

Wageningen Marine Research, instituut binnen de rechtspersoon Stichting

Wageningen Research, hierbij

vertegenwoordigt door Dr. M.C.Th. Scholten, Algemeen directeur

KvK nr. 09098104,

WMR BTW nr. NL 8113.83.696.B16.

Code BIC/SWIFT address: RABONL2U

IBAN code: NL 73 RABO 0373599285
Wageningen Marine Research aanvaardt geen aansprakelijkheid voor gevolgschade, noch voor schade welke voortvloeit uit toepassingen van de resultaten van werkzaamheden of andere gegevens verkregen van Wageningen Marine Research opdrachtgever vrijwaart Wageningen Marine Research van aanspraken van derden in verband met deze toepassing.

Alle rechten voorbehouden. Niets uit deze uitgave mag weergegeven en/of gepubliceerd worden, gefotokopieerd of op enige andere manier gebruikt worden zonder schriftelijke toestemming van de uitgever of auteur. 


\section{Inhoud}

Samenvatting

2 Methoden $\quad 6$

$\begin{array}{llr}3 & \text { Resultaten } & 8\end{array}$

3.1 Terugvangsten $\quad 8$

3.2 Verspreiding $\quad 9$

$\begin{array}{ll}3.3 & \text { Lengtemetingen } \\ \end{array}$

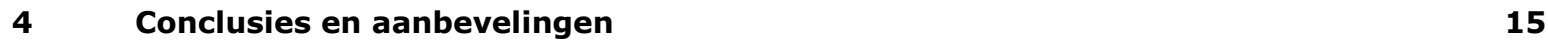

$\begin{array}{llr}5 & \text { Kwaliteitsborging } & 16\end{array}$

$\begin{array}{lr}\text { Literatuur } & 17\end{array}$

$\begin{array}{lr}\text { Verantwoording } & 18\end{array}$

$\begin{array}{llr}\text { Bijlage } 1 & \text { Fuiklocaties } & 19\end{array}$ 


\section{Samenvatting}

Het Hoogheemraadschap van Delfland (HHD) heeft de afgelopen jaren bijgedragen aan het verbeteren van de overlevingskansen van Europese aal (Anguilla anguilla) in het beheergebied. Er is geïnvesteerd in het vispasseerbaar maken van kunstwerken en het verbeteren van de (ecologische) waterkwaliteit. Ook is met de lokale beroepsvisserij overeengekomen te stoppen met aalvisserij in het gehele beheergebied van Delfland voor de periode $2017 \mathrm{t} / \mathrm{m} \mathrm{2022}$. Het is echter onbekend hoeveel glasaal het beheergebied op natuurlijke wijze binnenkomt, waar de aal heen gaat en hoe groot het aalbestand is. Delfland heeft dan ook besloten om in de periode 2017 t/m 2022 onderzoek te doen naar de intrek van glasaal en de aalpopulatie in het beheergebied. De beroepsvisserij wordt betrokken in deze onderzoeken.

Deze studie betreft een merk-terugvangstexperiment van rode aal in vijf deelgebieden in boezemwater van HHD: Berkelse Zweth, Nieuwe Water, Vlaardingse Vaart, Boonervliet en het Verversingskanaal nabij gemaal Schoute. Het doel van het onderzoek is het vaststellen van variatie in groei, opbouw van de aalpopulatie en verspreiding van rode aal in het beheergebied. Deze rapportage betreft een verslaglegging van het derde onderzoeksjaar (jaar 3). De werkzaamheden in van jaar 1 en jaar 2 zijn in aparte rapportages gepubliceerd. In het derde jaar is geprobeerd om de alen die in jaar 1 en jaar 2 zijn gemerkt terug te vangen en opnieuw op te meten. Het onderzoek wordt voortgezet met het (terug)vangen van rode aal in jaar 4 t/m 6 (2020-2022). In 2017 (jaar 1) en 2018 (jaar 2) zijn in totaal 1008 rode alen van een $12 \mathrm{~mm}$ PITtag voorzien. Het onderzoek wordt in het veld uitgevoerd door visserijbedrijf $W$. den Boer met ondersteuning van vrijwilligers van de Hengelsportvereniging SVBD (Sport Visserij Belangen Delfland), GHV / Groene Hart en medewerkers van Hoogheemraadschap van Delfland. Wageningen Marine Research begeleidt het onderzoek. De vrijwilligers van de SVBD, GHV / Groene Hart en medewerkers van Hoogheemraadschap van Delfland helpen niet alleen mee met het onderzoek, maar zorgen er ook voor dat er toezicht is bij alle veldwerkzaamheden.

In totaal zijn 186 alen teruggevangen van de 1008 gemerkte rode alen (18.5\%). De groeisnelheid ligt rond de $45 \mathrm{~mm}$ per jaar en er is variatie tussen de gebieden. Op basis van de teruggekoppelde data is de gemiddelde groeisnelheid bij het Nieuwe Water het hoogst (59mm per jaar). Echter, in dit gebied zijn ook de minste rode alen teruggevangen (2017-2018: 3 stuks en 2018-2019: 14 stuks), waardoor het gemiddelde minder betrouwbaar is in vergelijking tot de andere gebieden. De laagste gemiddelde groei wordt gemeten in het Verversingskanaal (28.0 mm/jaar). Er zijn binnen dit onderzoek diverse alen gevonden die over 1 of 2 jaar geen groei realiseerden. Hiervan zijn er relatief veel in het Verversingskanaal gevonden en zorgen voor het lage gemiddelde aan groei.

Deze rapportage betreft een tussenrapportage, een data rapportage. In de aankomende jaren wordt het onderzoek voortgezet en zal in 2022 afgesloten worden met een uitgebreidere rapportage en analyse. 


\section{$1 \quad$ Inleiding}

Het Hoogheemraadschap van Delfland (HHD) heeft de afgelopen jaren bijgedragen aan het verbeteren van de overlevingskansen van Europese aal in het beheergebied. $\mathrm{Er}$ is geïnvesteerd in het vispasseerbaar maken van kunstwerken en het verbeteren van de (ecologische) waterkwaliteit. Ook is met de lokale beroepsvisserij overeengekomen te stoppen met aalvisserij in het gehele beheergebied van Delfland voor de periode $2017 \mathrm{t} / \mathrm{m} \mathrm{2022}$. Het is echter onbekend hoeveel glasaal het beheergebied op natuurlijke wijze binnenkomt, waar de aal heen gaat en hoe groot het aalbestand is. Delfland heeft dan ook besloten om in de periode 2017 t/m 2022 onderzoek te doen naar de intrek van glasaal (Griffioen et al. 2018) en de aalpopulatie in het beheergebied. De beroepsvisserij wordt betrokken bij deze onderzoeken.

Aal is een soort die door internationale wateren zwemt. Een gezonde aalpopulatie is daarmee afhankelijk van verschillende factoren zoals vrije migratie tussen opgroei,- en paaigebieden. Het Hoogheemraadschap van Delfland wil investeren in deze vrije migratie en daarnaast ook de opgroeigebieden in hun beheer goed onderhouden. Goed gefaciliteerde intrek van glasaal, een goede leefomgeving voor rode aal en effectieve uittrekmogelijkheden van volwassen schieraal binnen Delfland zal bijdragen aan de lokale, maar ook de algehele Europese aalpopulatie.

Deze studie betreft een merk-terugvangstexperiment van rode aal in vijf deelgebieden in boezemwateren van HHD. Het doel van het onderzoek is het vaststellen van variatie in groei en verspreiding van rode aal. Deze rapportage betreft een verslaglegging (datarapportage) van het derde onderzoeksjaar (jaar 3). Het onderzoek wordt voortgezet met het (terug)vangen van rode aal in jaar 4 t/m 6 (2020-2022).

Dit onderzoek wordt begeleid door WMR en in het veld uitgevoerd door visserijbedrijf W. den Boer met ondersteuning van vrijwilligers van de Hengelsportvereniging SVBD (Sport Visserij Belangen Delfland), GHV / Groene Hart en medewerkers van Hoogheemraadschap van Delfland. De vrijwilligers van de SVBD, GHV / Groene Hart en medewerkers van Hoogheemraadschap van Delfland helpen niet alleen mee met het onderzoek, maar zorgen er ook voor dat er toezicht is bij alle veldwerkzaamheden.

Doel van het onderzoek:

Onderzoek naar de variatie in groeisnelheid en verspreiding van rode aal in het gebeid van HHD. De gegevens worden ook gebruikt voor een populatieschatting op basis van merk-terugvangst.

\section{Onderzoeksvraag:}

Wat is de groeisnelheid van (rode) aal in het beheergebied van HHD en wat is de variatie tussen deelgebieden? Wat is de omvang van de rode aalpopulatie in de onderzochte deelgebieden van HHD en is er meer inzicht te krijgen in de migratieroutes van de aal in het beheergebied? Deze rapportage gaat alleen in op de groeisnelheid van rode aal en eventuele verspreiding van aal in het gebied. 


\section{Methoden}

In het beheergebied van HHD werd in 2017 en 2018 met behulp van fuiken rode aal gevangen in vijf gebieden in boezemwater (Figuur 1). De rode alen worden verdoofd in een oplossing van $0.5 \mathrm{ml} / \mathrm{L} 1$ phenoxy ethanol. Vervolgens werden de alen gemerkt met een $12 \mathrm{~mm}$ HDX-PITtag die met een naald wordt ingebracht in de rugspier naast de rugvin. Elke tag heeft een unieke code. De code wordt afgelezen met een manual PITtag reader. Het plaatsen van de fuiken en het zetten van de $12 \mathrm{~mm}$ PITtags is, na instructie van WMR in het veld voor het zetten van de PITtags en het vrijgeven van een ontheffing, zelfstandig uitgevoerd door visserijbedrijf W. den Boer. De rode alen werden (verdoofd) in millimeter tot op één decimaal nauwkeurig gemeten in een V-vormige aalmeetbak. In $2017(n=336)$ en 2018 $(n=672)$ zijn in totaal 1008 rode alen gemerkt met een PITtag. In 2019 t/m 2022 worden er vooralsnog geen rode alen meer gemerkt met PITtag; het aantal van 1008 gemerkte rode alen wordt voldoende geacht voor dit onderzoek. Op foto 1-4 zijn ter indicatie enkele handelingen van het (terug)vangen en meten weergegeven.

Binnen de studie zijn de deelgebieden Vlaardingse Vaart en Boonervliet samengevoegd, omdat de wateren met elkaar in verbinding staan én de fuiken relatief dicht bij elkaar staan (Figuur 1).

Ten opzichte van de voorgaande rapportage \{Griffioen, 2018 \#1527\} zijn, op basis van nieuw verkregen data in 2019, een aantal aanpassingen doorgevoerd in de database of is data verwijderd door onduidelijkheden op veldformulieren.

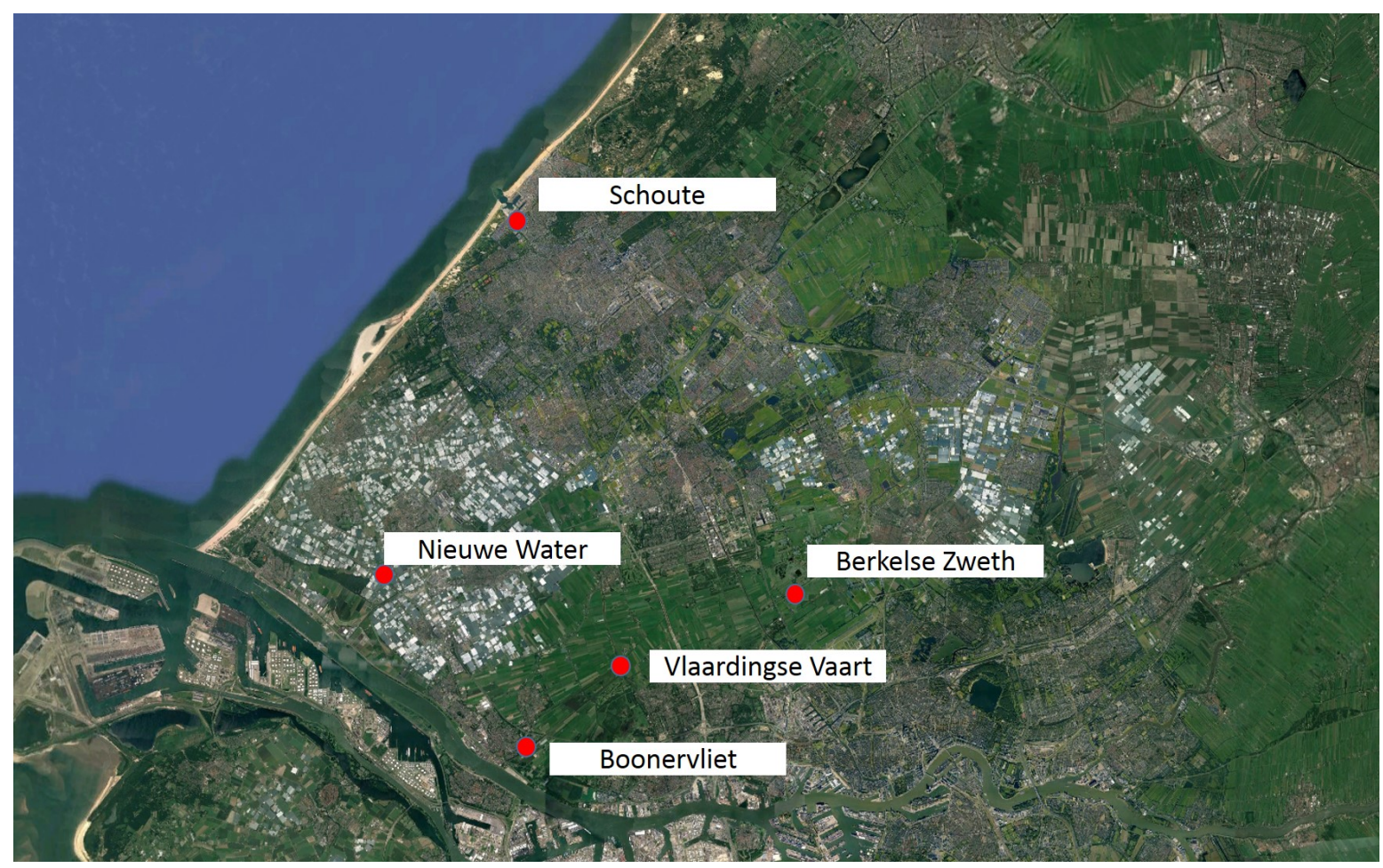

Figuur 1. De vijf deelgebieden waar het onderzoek is uitgevoerd.

Op elke locatie zijn vier fuiken geplaatst. De fuiken in de vangstperiode zijn twee keer verplaatst met de gedachte dat rode aal soms zeer lokaal actief is. Een andere locatie zou nieuwe vangsten opleveren. De monitoring in 2019 is gestart op 17 april 2019 met 21 fuiken en geëindigd op 29 mei 2019. De fuiken zijn om de drie dagen gelicht: 20, 23, 26 en 29 april, 2, 5, 8, 11, 14, 17, 20, 23, 26 en 29 mei 2019. In totaal zijn 14 lichtingen uitgevoerd. 


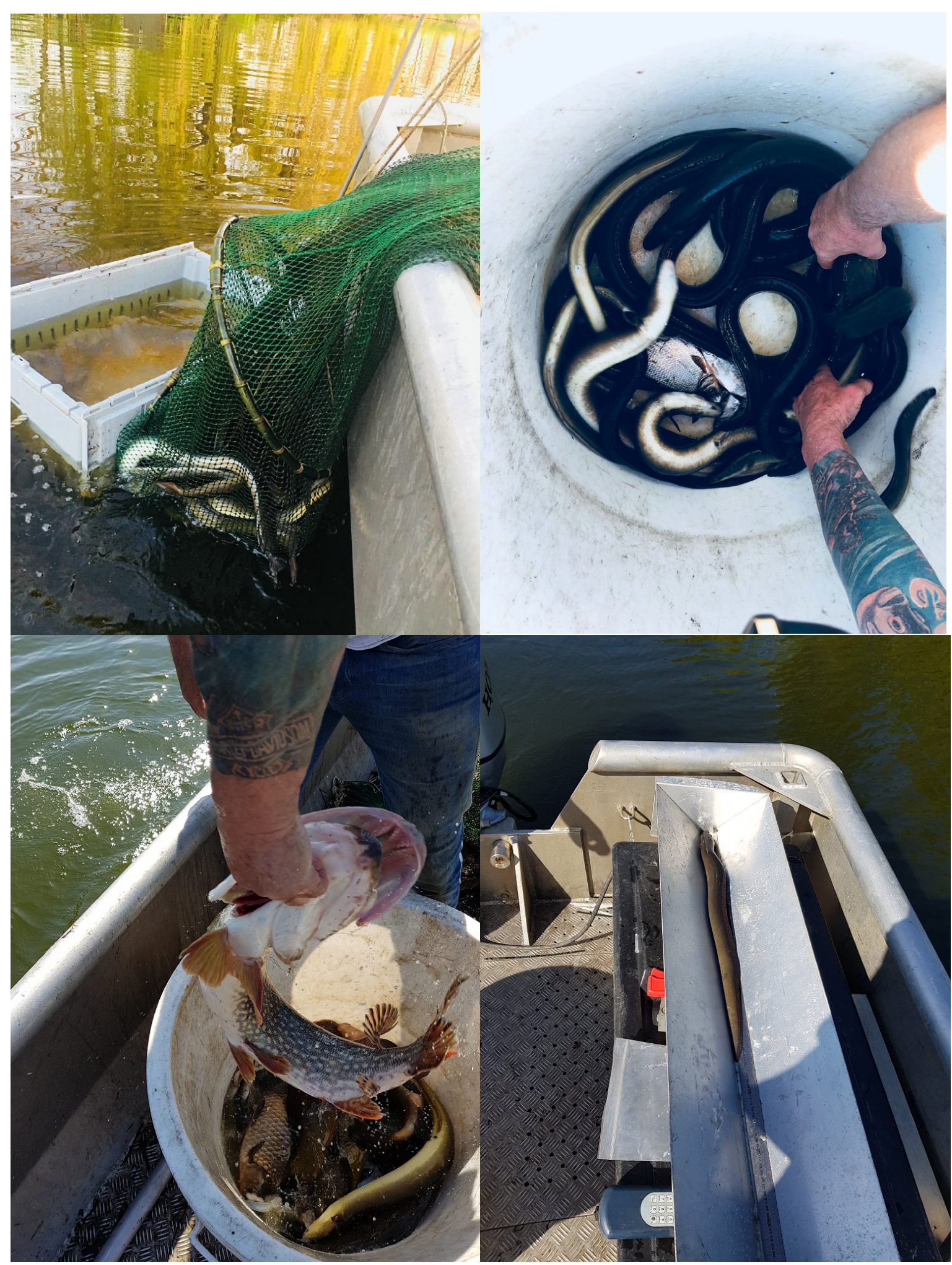

Foto 1-4. Foto's van het veldwerk. Links boven: vangst wordt opgehaald uit een fuik. Rechts boven: vangst wordt gesorteerd en gescand op terugvangsten. Linksonder: bijvangst wordt direct teruggezet (hier een snoek en een giebel). Rechtsonder: rode aal wordt verdoofd opgemeten in een aalgoot. 


\section{Resultaten}

\subsection{Terugvangsten}

In 2018 en 2019 zijn binnen het onderzoek meerdere terugvangsten gemeld van vissen die na één of twee jaar weer zijn teruggevangen. In totaal zijn dit 186 stuks. Het terugvangstpercentage voor alle gemerkte alen is $186^{1} / 1008=18.5 \%$, dit zijn de alen die minimaal éénmaal zijn teruggevangen na 1 of 2 jaar. Dit kunnen we onderverdelen in de volgende percentages:

52 stuks 2017 gemerkt, 2018 teruggevangen (terugvang: 52/336=15.5\%)

13 stuks 2017 gemerkt, 2019 teruggevangen (terugvang: $13 / 336=3.9 \%$ )

17 stuks 2017 gemerkt, teruggevangen in 2018 en 2019 (terugvang: 17/336=5.1\%)

104 stuks 2018 gemerkt, 2019 teruggevangen (terugvang: 104/672=15.5\%)

Indien we rekening houden met terugvangsten inclusief individuen die binnen hetzelfde jaar (enkele dagen of weken na het merken) is het terugvangstpercentage $30.2 \%$ van alle gemerkte vissen (Tabel 1). Het terugvangstpercentage van individuen in het Boonervliet/Vlaardingsevaart is $22.8 \%$, Berkelse Zweth 35\%, Nieuwe Water 34.7\% en Verversingskanaal 58.3\%. Daarnaast zijn er ook alen die meerdere malen zijn teruggevangen, tot wel 10x in totaal over de jaren 2017-2019 (aal \#941413 Figuur 6-rechts, Tabel 1). Sommige alen zijn binnen hetzelfde jaar meerdere malen teruggevangen (meer dan één keer teruggevangen).

Naast de gemerkte rode aalvangsten zijn in 2019 ook 507 ongemerkte rode alen gevangen en 89 ongemerkte schieralen. Daarnaast zijn in de fuiken niet alleen alen gevangen, maar ook bijvangsten zoals grote zeelt, brasem, giebel en snoek. Aan deze bijvangsten wordt in dit onderzoek geen aandacht besteed.

Tabel 1. Overzicht van gerapporteerde (terug)vangsten gedurende de periode in 2017 tot 2019. Individuele terugvangsten kunnen ook binnen hetzelfde jaar zijn gedaan.

\begin{tabular}{|c|c|c|c|c|c|c|c|}
\hline & & & BO/VV & BZ & NW & VK & totaal \\
\hline \multirow[t]{3}{*}{ gemerkt } & 2017 & $\mathrm{n}$ & 208 & 90 & 13 & 25 & 336 \\
\hline & 2018 & $n$ & 388 & 124 & 82 & 78 & 672 \\
\hline & totaal & $\mathrm{n}$ & 596 & 214 & 95 & 103 & 1008 \\
\hline \multirow[t]{11}{*}{ terugvangst } & $1 x$ & $n$ & 136 & 75 & 33 & 60 & 304 \\
\hline & $2 x$ & $n$ & 41 & 30 & 8 & 35 & 114 \\
\hline & $3 x$ & $n$ & 16 & 13 & 1 & 17 & 47 \\
\hline & $4 \mathrm{x}$ & $\underline{\mathrm{n}}$ & 6 & 5 & 1 & 8 & 20 \\
\hline & $5 x$ & $n$ & 1 & 1 & & 6 & 8 \\
\hline & $6 x$ & $n$ & 1 & & & 4 & 5 \\
\hline & $7 x$ & $n$ & 1 & & & 2 & 3 \\
\hline & $8 x$ & $n$ & & & & 2 & 2 \\
\hline & $9 x$ & $n$ & & & & 1 & 1 \\
\hline & $10 x$ & $n$ & & & & 1 & 1 \\
\hline & totaal & $n$ & 202 & 124 & 43 & 136 & 505 \\
\hline \multirow[t]{2}{*}{ terugvangst } & individuen* & $n$ & 136 & 75 & 33 & 60 & 304 \\
\hline & & $\%$ & 22.8 & 35.0 & 34.7 & 58.3 & 30.2 \\
\hline rode aal & ongemerkt, 2019 & $n$ & 251 & 108 & 109 & 39 & 507 \\
\hline schieraal & ongemerkt, 2019 & $n$ & 15 & 2 & 4 & 68 & 89 \\
\hline
\end{tabular}

*dit getal is incl. gemerkte individuen die hetzelfde jaar (2017, 2018 of 2019) zijn teruggevangen binnen enkele dagen/weken.

\footnotetext{
${ }^{1}$ Van één aal (\#941552) was de lengtemeting onduidelijk en daarom wordt deze in tabel 2 niet opgenomen in de gemiddelde berekeningen. In tabel 2 zijn 202 metingen meegenomen. Dit is inclusief 17 alen waar 2 keer een jaarlijkse groei is vastgesteld: gevangen in 2017, 2018 én 2019. 202-17=185 alen.
} 


\subsection{Verspreiding}

In totaal zijn 4 alen in een ander gebied teruggevangen dan waarin ze gemerkt werden. Aal \#942210 is gemerkt in Boonervliet/Vlaardingse Vaart en enkele dagen later teruggevangen in het Nieuwe Water. Aal \#943231 idem, maar daar zat een jaar tussen (2018 gemerkt, 2019 teruggevangen). Aal \#942046 is gevangen en gemerkt in Boonervliet/Vlaardingse Vaart in 2018. Deze aal wordt in 2018 teruggevangen in de Berkelse Zweth en een jaar later weer teruggevangen in Boonervliet/Vlaardingse Vaart. Aal \#941558 maakt volgens de data ook een uitstapje in een relatief korte tijd.
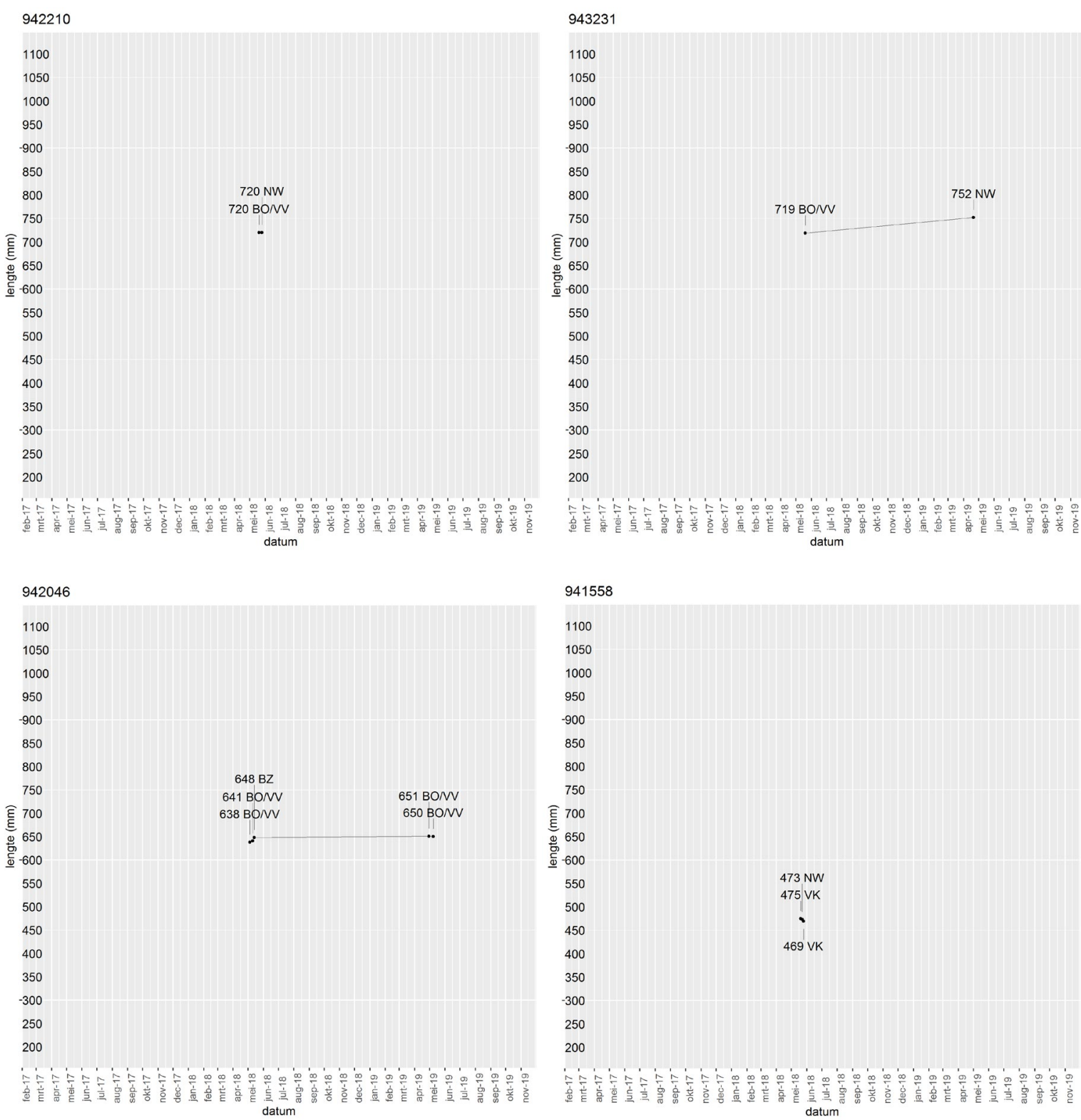

Figuur 2. Individuen die worden gerapporteerd als terugvangsten, waarbij de terugvangstlocatie een andere locatie is dan de merklocatie. 


\subsection{Lengtemetingen en groeisnelheid}

De groeisnelheid per teruggevangen aal wordt bepaald door het verschil in lengte $(\mathrm{mm})$ en tijdverschil. In de berekening van de groeisnelheid is, in het geval van meerdere terugvangsten, de laatste lengtemeting van jaar $\mathrm{n}$ afgetrokken van de eerste lengtemeting van jaar $\mathrm{n}+1$. Dit lengteverschil is gedeeld door het aantal dagen tussen de waarnemingen en vermenigvuldigd met 365 dagen. Dit resulteert in een groeisnelheid in $\mathrm{mm} / \mathrm{jaar}$ (Tabel 2, Figuur 3). Bij meerdere lengtemetingen per jaar (zoals in Figuur 4) is het ook een optie om in vervolgrapportages te rekenen met een gemiddelde lengtemeting per jaar en een gemiddelde tijd van alle waarnemingen.

Tabel 2. Overzicht van groeisnelheden omgerekend naar groei per 365 dagen. NB. Sommige vissen zijn meerdere malen teruggevangen. In de berekening is de laatste (of enige) meting van jaar $n$ afgetrokken van de meting van jaar $n+1$ gedeeld door het verschil in dagen tussen de waarnemingen (=groeisnelheid). In de tabel zijn deze waarden omgerekend naar groeisnelheden per jaar (365 dagen).

\begin{tabular}{|l|l|l|r|r|r|r|r|}
\hline & & BO/VV & BZ & NW & VK & totaal \\
\hline rode aal & $2017-2018$ & $\mathrm{n}$ & 27 & 27 & 3 & 13 & 70 \\
\hline & 1 jaar groei & avg/jaar $(\mathrm{mm})$ & 41.6 & 52.5 & 47.6 & 38.8 & 45.1 \\
\hline rode aal & $2018-2019$ & $\mathrm{n}$ & 46 & 22 & 14 & 37 & 119 \\
\hline & 1 jaar groei & avg/jaar $(\mathrm{mm})$ & 47.5 & 44.4 & 61.8 & 25.2 & 44.7 \\
\hline rode aal & $2017-2019$ & $\mathrm{n}$ & 4 & 6 & 0 & 3 & 13 \\
\hline & 2 jaar groei & avg/jaar $(\mathrm{mm})$ & 31.7 & 43.7 & & 16.8 & 30.7 \\
\hline rode aal & alle gegevens & $\mathrm{n}$ & 77 & 55 & 17 & 53 & 202 \\
\hline & 1 of 2 jaar groei & avg/jaar $(\mathrm{mm})$ & 44.6 & 48.3 & 59.3 & 28.0 & 45.1 \\
\hline
\end{tabular}

De groeisnelheid ligt gemiddeld rond de $45 \mathrm{~mm}$ per jaar (Tabel 2, gemiddelde over alle gegevens), maar kent variatie tussen gebieden. De groei in het Nieuwe Water ligt het hoogst met $59.3 \mathrm{~mm}$ per jaar en is het laagst bij het Verversingskanaal met $28 \mathrm{~mm}$ per jaar (Tabel 2, gemiddelde over alle gegevens en dus 1 of 2 jaren groei). 

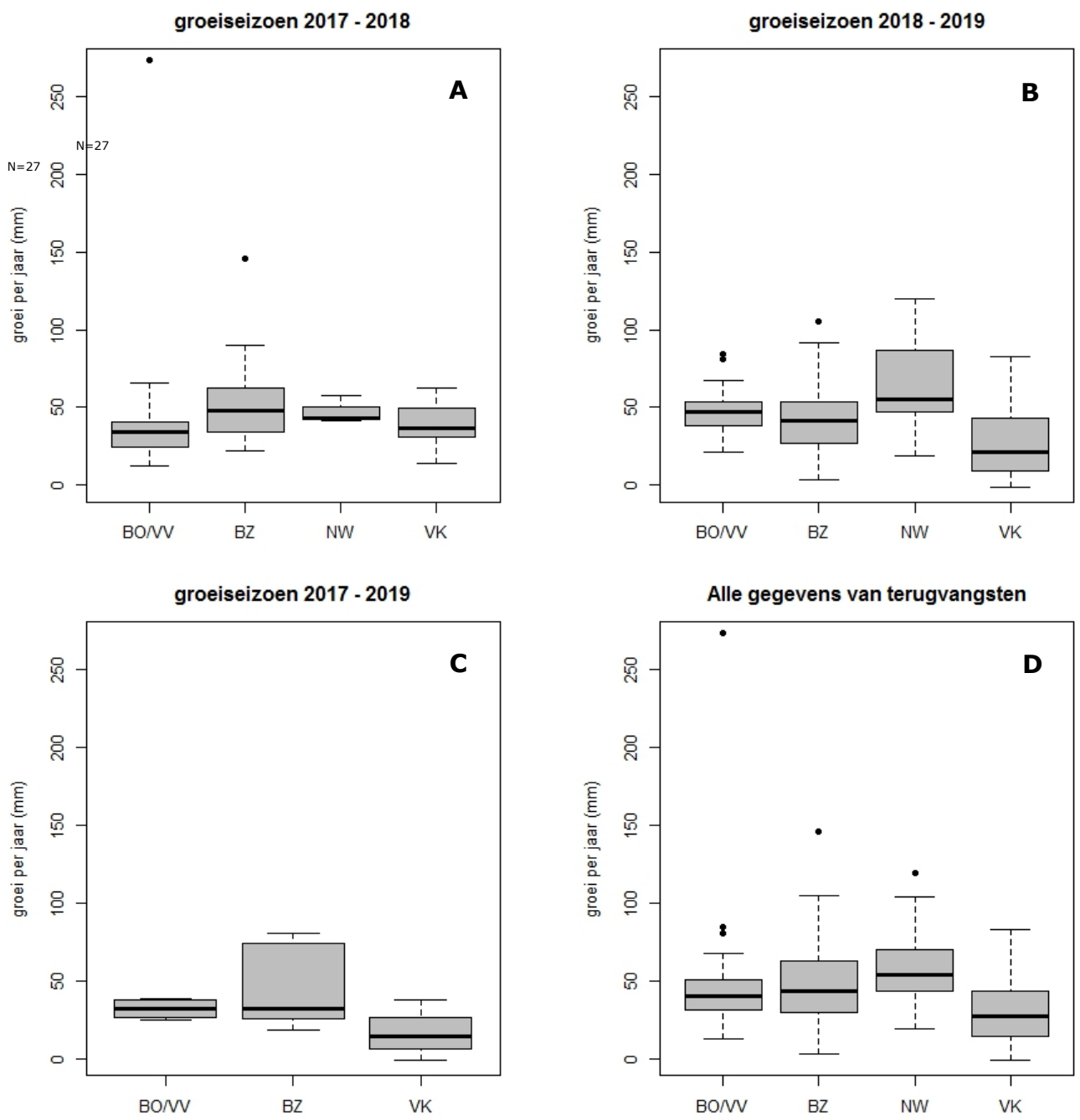

Figuur 3. Grafische weergave van Tabel 2 incl. spreiding van gegevens per gebied. Grafieken geven de gemiddelde groei $(\mathrm{mm})$ en de verdeling van de data per jaar per gebied. A: de alen die zijn gemerkt in 2017 en zijn teruggevangen in 2018. B: de alen die in 2018 zijn gemerkt (of gemeten) en in 2019 zijn teruggevangen. C: De alen die in 2017 zijn gemerkt en in 2019 zijn teruggevangen. D: alle gegevens van $A$, $B$ en $C$. $B V=$ Boonervliet, $V V=$ Vlaardingse Vaart, $B Z=$ Berkelse $Z$ weth, $N W=$ Nieuwe Water, $V K=$ Verversingskanaal. 
Binnen deze datarapportage worden enkele interessante voorbeelden gegeven van lengteverschil in de tijd (Figuren 4-6). In sommige gevallen is een lengte gemeten met circa $1 \mathrm{~cm}$ verschil binnen enkele dagen (Figuur 4 links). Dit lijkt te duiden op een meetfout, te meer omdat een eerste meting circa $1 \mathrm{~cm}$ afwijkt van drie vervolg metingen. In andere gevallen is de lengtemeting zeer consequent (Figuur 4 rechts en Figuur 5). Er zijn ook alen die geen groei laten zien over een periode van 1 of 2 jaar (Figuur 6). Mogelijk zijn dit mannetjes die aan het einde van hun groei zitten.

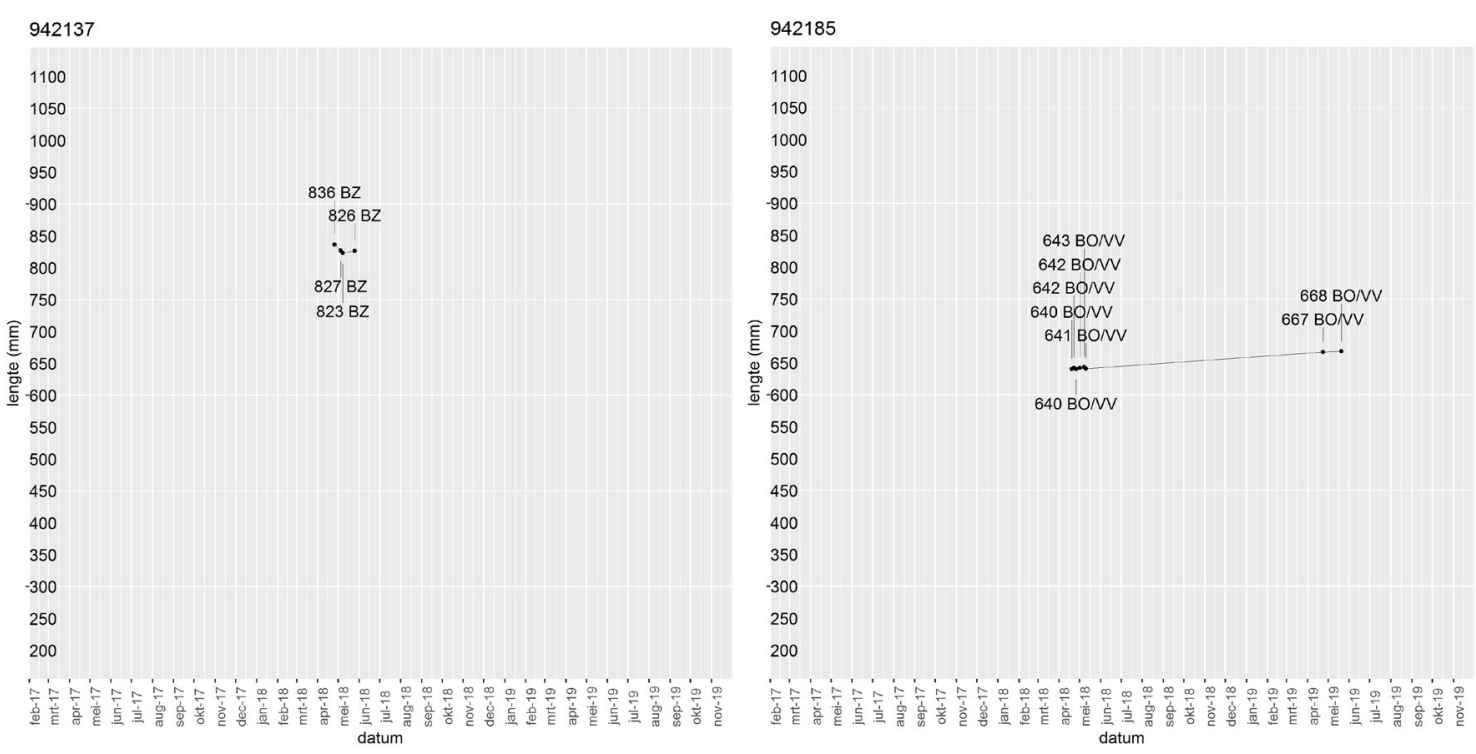

Figuur 4. Links een rode aal waarvan de lengtemeting binnen het seizoen met circa $1 \mathrm{~cm}$ afweek. Recht een rode aal met lengtemetingen die enkele millimeters van elkaar verschillen binnen een seizoen. De getallen in de figuur is de lengte in $\mathrm{mm}$.
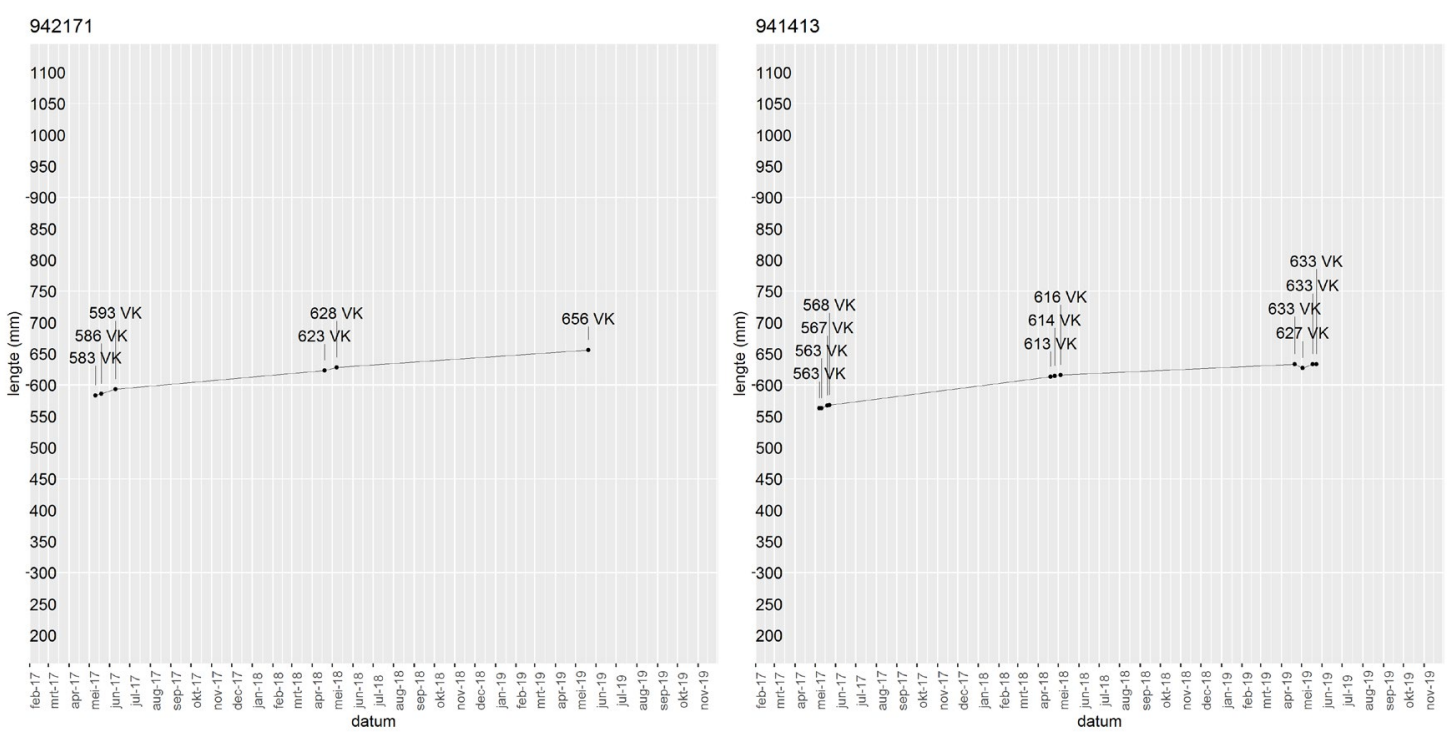

Figuur 5. Een aal waarvan er een vrij consequente groei zichtbaar is (links) en een aal waarbij het tweede jaar een minder sterkte groei was (rechts). De getallen in de figuur is de lengte in $\mathrm{mm}$. 

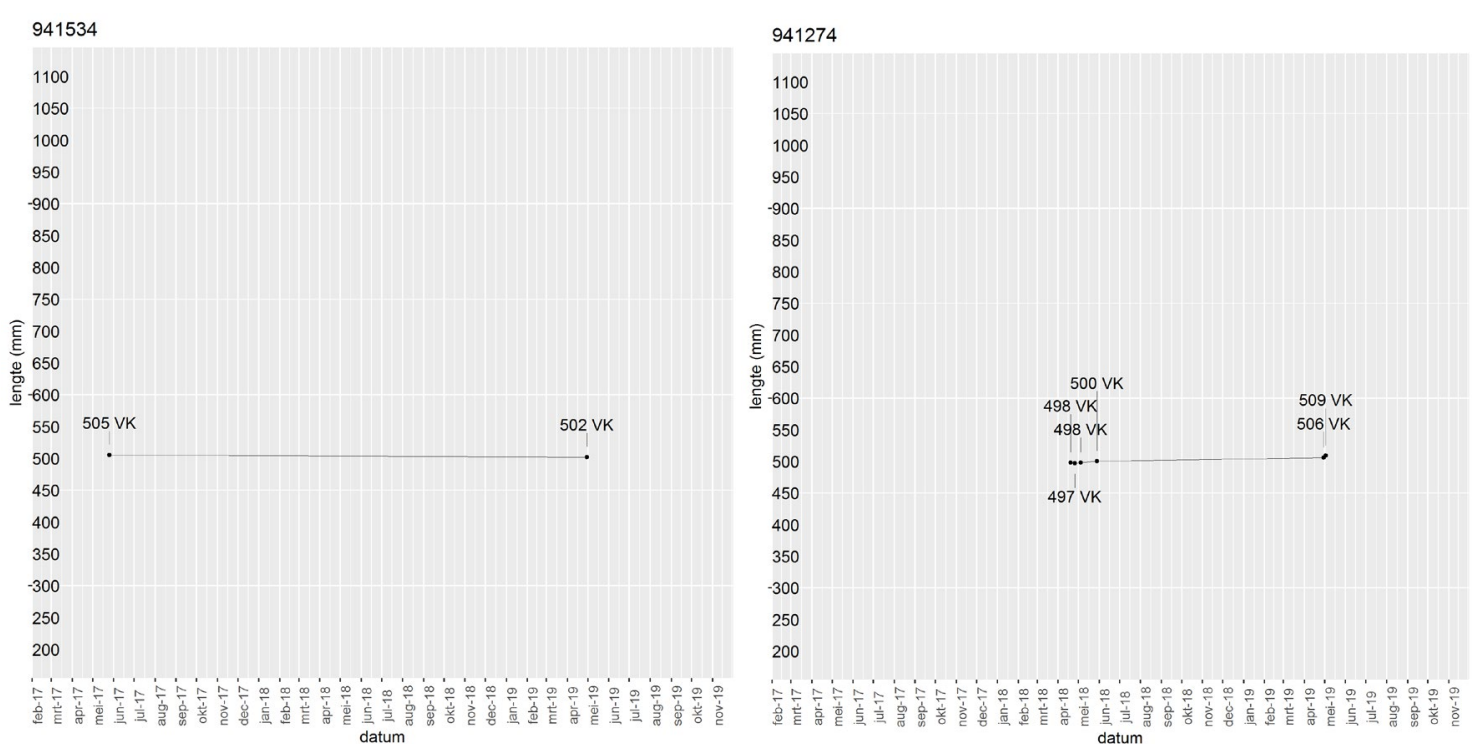

Figuur 6. Rode alen waarbij er nauwelijks lengteverschil is waargenomen over een periode van 1-2 jaar. De getallen in de figuur is de lengte in $\mathrm{mm}$.

De lengte van rode alen gevangen in het gebied spreidt zich over een range van $>25-90 \mathrm{~cm}$ (Figuur 7 en 8). Echter, in het Verversingskanaal lijken er relatief meer kleinere alen gevangen te worden met een piek rond de $50 \mathrm{~cm}$. Bij de andere gebieden ligt deze piek rond de $65 \mathrm{~cm}$.

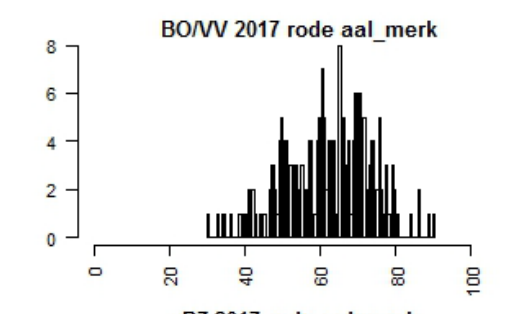

LF gemerkte rode alen (gemerkt en terugvangst)
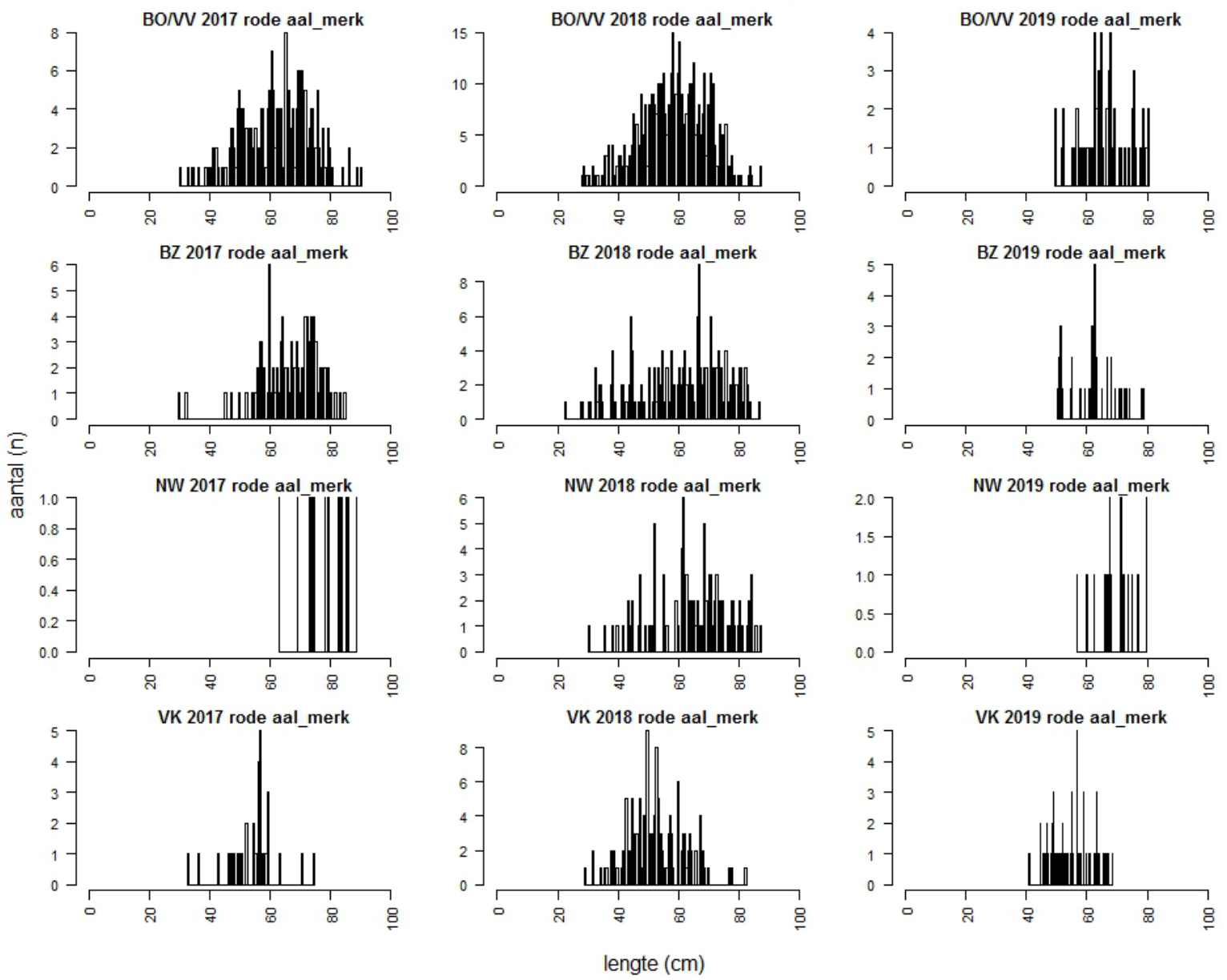

Figuur 7. Lengtefrequentieverdeling ( $\mathrm{cm}$ op de $X$-as) van de vangsten in vier deelgebieden waar het onderzoek is uitgevoerd in 2017, 2018 en 2019. BV = Boonervliet, VV = Vlaardingse Vaart, BZ = Berkelse Zweth, NW = Nieuwe Water, $V K=$ Verversingskanaal. 


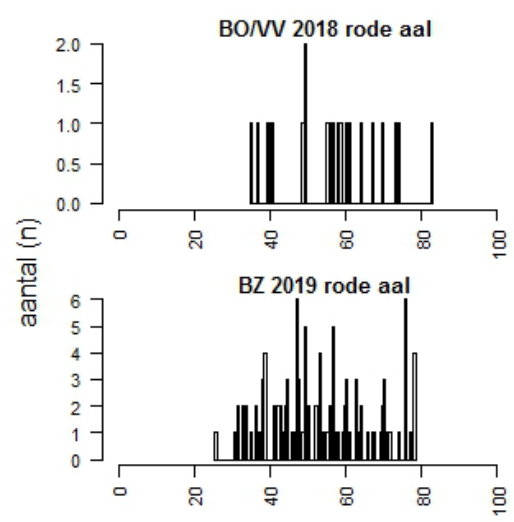

LF gemerkte rode alen (ongemerkt)
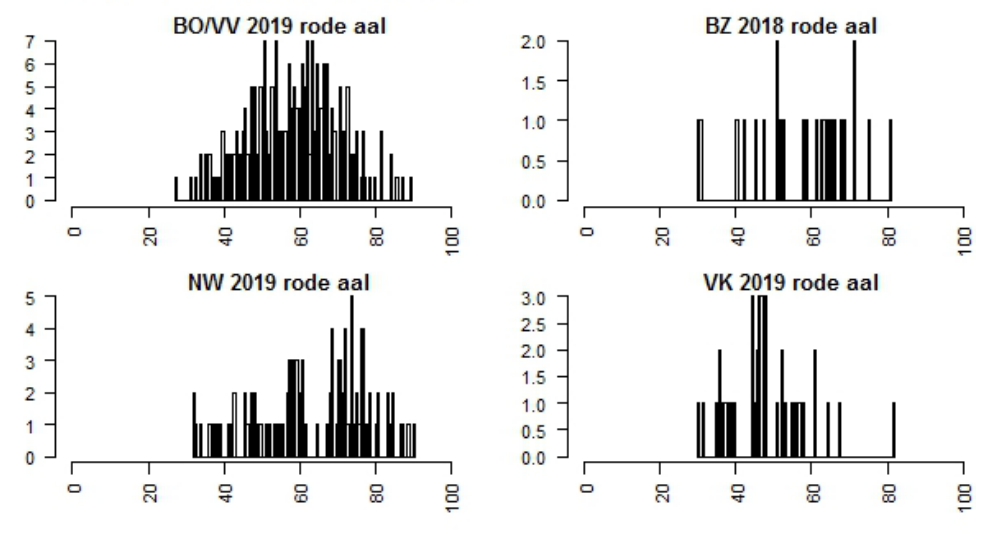

lengte $(\mathrm{cm})$

Figuur 8. Lengtefrequentieverdeling ( $\mathrm{cm}$ op de $X$-as) van vangsten van ongemerkte rode alen in de vier deelgebieden waar het onderzoek is uitgevoerd in 2018 en 2019. BV = Boonervliet, VV = Vlaardingse Vaart, $B Z=$ Berkelse Zweth, $N W=$ Nieuwe Water,$V K=$ Verversingskanaal.

Naast rode alen zijn ook schieralen opgemeten. Voornamelijk in het Verversingskanaal worden relatief veel schieralen gevangen (Figuur 9). Baserend op de lengte betreffen dit vooral vrouwelijke schieralen $(>50 \mathrm{~cm})$ en enkele mannetjes $(<50 \mathrm{~cm})$.
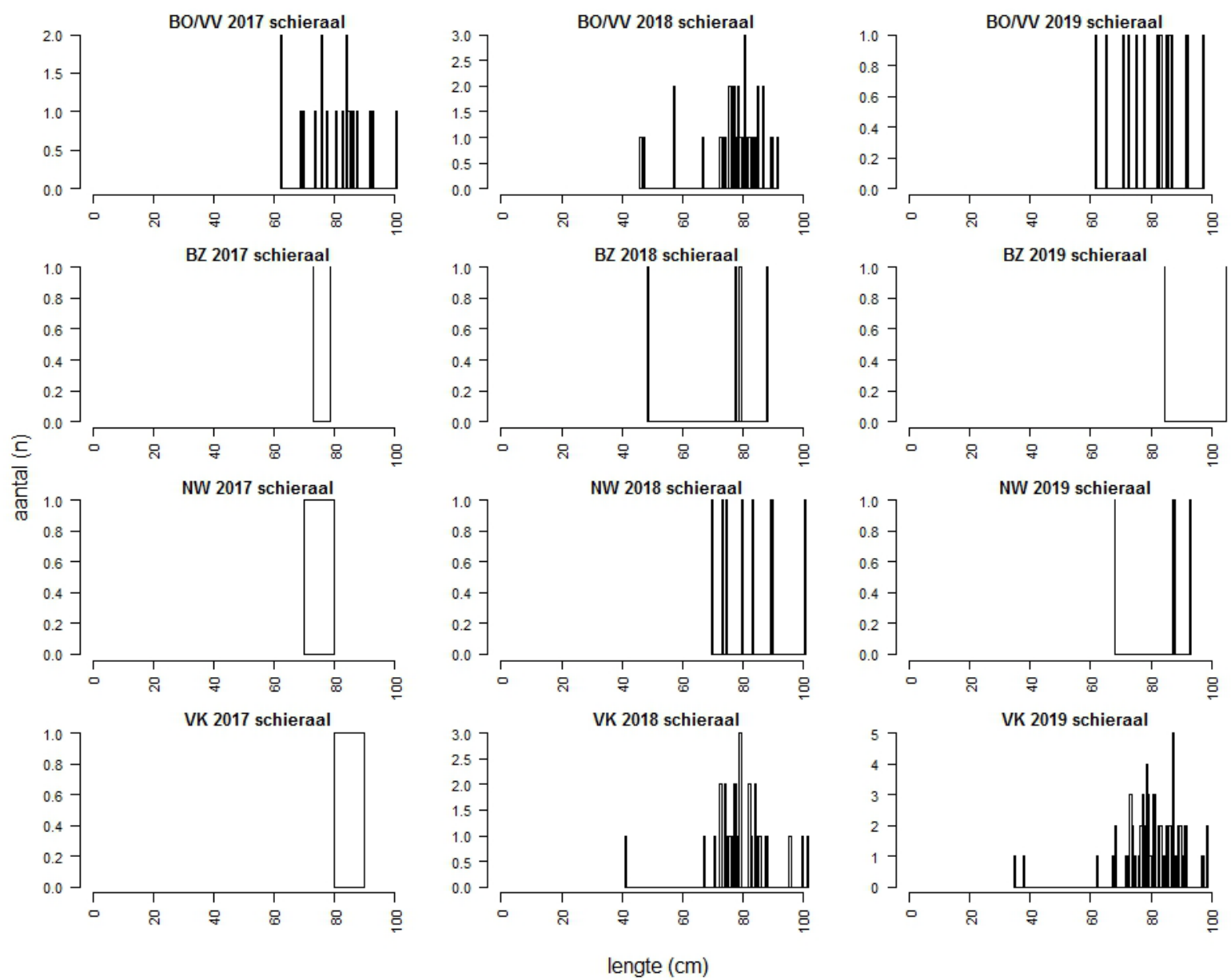

Figuur 9. Lengtefrequentieverdelingen ( $\mathrm{cm}$ op de $X$-as) van schieralen per jaar en gebied. BV = Boonervliet, $V V=$ Vlaardingse Vaart, $B Z=$ Berkelse $Z$ weth, $N W=$ Nieuwe Water, $V K=$ Verversingskanaal. 


\section{$4 \quad$ Conclusies en aanbevelingen}

Het doel van de rapportage is een weergave te geven van de gemiddelde groei van rode aal in de diverse gebieden. In totaal zijn 186 alen teruggevangen van de 1008 gemerkte rode alen (18.5\%). De groeisnelheid ligt gemiddeld rond de $45.1 \mathrm{~mm}$ per jaar, en is er variatie tussen de gebieden (Tabel 2 en Figuur 3). Op basis van de teruggekoppelde data is de gemiddelde snelheid bij het Nieuwe Water het hoogst (59.3 mm per jaar). Echter, in dit gebied zijn ook de minste rode alen teruggevangen (20172018: 3 stuks en 2018-2019: 14 stuks), dus het gemiddelde is daar het minst betrouwbaar. De laagste gemiddelde groei werd gemeten in het Verversingskanaal $(28.0 \mathrm{~mm}$ per jaar). Er zijn binnen dit onderzoek diverse alen gevonden die over 1 of 2 jaren geen groei lijken te realiseren. Hiervan zijn er relatief veel gevonden in het Verversingskanaal, die drukken op de gemiddelde groei. De lengtefrequentiegrafiek van het Verversingskanaal laat ook zien dat in het Verversingskanaal relatief kleinere alen aanwezig zijn dan in de andere gebieden. Rode aal lijkt (gedurende deze tijdsperiode) nauwelijks tussen de verschillende gebieden te bewegen; er zijn slechts 4 gevallen gemeld waarbij de rode alen in een ander gebied zijn teruggevangen.

\section{Aanbevelingen}

De ontvangen veldformulieren bevatten soms onlogische notities voor locaties, lengtematen en/of PITtag-nummers. Alle wijzingen/suggesties worden bijgehouden in het databestand in beheer bij WMR. Aanbevolen wordt om de veldmetingen zorgvuldig uit te voeren en het gescande nummer en de lengtemaat van de aal door twee mensen te laten controleren. Aanbevolen wordt om de lengtemetingen onder verdoving voort te zetten zoals ook gebeurd is in voorgaande jaren. De verdoving is noodzakelijk om lengtemetingen nauwkeurig uit te voeren. Daarnaast zorgt de verdoving voor spierontspanning die een andere lengtemeting zou kunnen geven in vergelijking met een niet verdoofde aal. 


\section{$5 \quad$ Kwaliteitsborging}

Wageningen Marine Research beschikt over een ISO 9001:2015 gecertificeerd kwaliteitsmanagementsysteem. Dit certificaat is geldig tot 15 december 2018. De organisatie is gecertificeerd sinds 27 februari 2001. De certificering is uitgevoerd door DNV GL.

Het chemisch laboratorium te IJmuiden beschikt over een NEN-EN-ISO/IEC 17025:2005 accreditatie voor testlaboratoria met nummer L097. Deze accreditatie is geldig tot 1 april 2021 en is voor het eerst verleend op 27 maart 1997; deze accreditatie is verleend door de Raad voor Accreditatie. Het chemisch laboratorium heeft hierdoor aangetoond in staat te zijn op technisch bekwame wijze valide resultaten te leveren en te werken volgens de ISO17025 norm. De scope (L097) met de geaccrediteerde analysemethoden is te vinden op de website van de Raad voor Accreditatie (www.rva.nl).

Op grond van deze accreditatie is het kwaliteitskenmerk $\mathrm{Q}$ toegekend aan de resultaten van die componenten die op de scope staan vermeld, mits aan alle kwaliteitseisen is voldaan. Het kwaliteitskenmerk Q staat vermeld in de tabellen met de onderzoeksresultaten. Indien het kwaliteitskenmerk $Q$ niet staat vermeld is de reden hiervan vermeld.

De kwaliteit van de analysemethoden wordt op verschillende manieren gewaarborgd. De juistheid van de analysemethoden wordt regelmatig getoetst door deelname aan ringonderzoeken waaronder die georganiseerd door QUASIMEME. Indien geen ringonderzoek voorhanden is, wordt een tweede lijnscontrole uitgevoerd. Tevens wordt bij iedere meetserie een eerstelijnscontrole uitgevoerd. Naast de lijnscontroles wordende volgende algemene kwaliteitscontroles uitgevoerd:

- Blanco onderzoek.

- Terugvinding (recovery).

- $\quad$ Interne standaard voor borging opwerkmethode.

- Injectie standard.

- Gevoeligheid.

Bovenstaande controles staan beschreven in Wageningen Marine Research werkvoorschrift ISW 2.10.2.105.

Indien gewenst kunnen gegevens met betrekking tot de prestatiekenmerken van de analysemethoden bij het chemisch laboratorium worden opgevraagd.

Indien sprake is van onbeheerste kwaliteit worden passende maatregelen genomen. 


\section{Literatuur}

Griffioen, A. B., M. E. Schiphouwer, H. V. Winter, and S. Ploegaert. 2018 Aalonderzoeken Hoogheemraadschap van Delfland: efficiëntie van glasaalintrek bij gemaal Schoute Wageningen Marine Research report C007.18. 


\section{Verantwoording}

Rapport C131/19

Projectnummer: 4316100192

Dit rapport is met grote zorgvuldigheid tot stand gekomen. De wetenschappelijke kwaliteit is intern getoetst door een collega-onderzoeker en het verantwoordelijk lid van het managementteam van Wageningen Marine Research

Akkoord:

Jip Vrooman

Onderzoeker

Handtekening:

Datum:

16 december 2019

Akkoord:

Jakob Asjes

MT-lid

Handtekening:

Datum:

16 december 2019 


\section{Bijlage 1 Coordinaten fuiklocaties}

\begin{tabular}{|l|l|l|l|l|l|l|l|}
\hline & \multicolumn{2}{|c|}{2019 periode 1} & 2019 & periode 2 & 2019 & periode 3 \\
\hline & X & y & x & y & x & y \\
\hline Berkelsche Zweth & 078448 & 437446 & 88962 & 443452 & 088854 & 443383 \\
\hline Berkelsche Zweth & 078028 & 437156 & 88708 & 443292 & 088571 & 443194 \\
\hline Berkelsche Zweth & 078622 & 437579 & 88450 & 443142 & 088154 & 442956 \\
\hline Berkelsche Zweth & 079995 & 438644 & 88063 & 442888 & 087875 & 442764 \\
\hline Boonervliet/Vlaardingese Vaart & 080469 & 439178 & 78325 & 437356 & 078213 & 437282 \\
\hline Boonervliet/Vlaardingese Vaart & 081291 & 439708 & 77941 & 437114 & 077841 & 437063 \\
\hline Boonervliet/Vlaardingese Vaart & 081809 & 439592 & 78795 & 437717 & 078981 & 437899 \\
\hline Boonervliet/Vlaardingese Vaart & 081897 & 439742 & 79839 & 438556 & 079682 & 438434 \\
\hline Boonervliet/Vlaardingese Vaart & 073520 & 443075 & 80393 & 439241 & 080458 & 439127 \\
\hline Boonervliet/Vlaardingese Vaart & 073540 & 442219 & 81494 & 439867 & 081746 & 440053 \\
\hline Boonervliet/Vlaardingese Vaart & 073198 & 443480 & 81882 & 439817 & 081752 & 440058 \\
\hline Boonervliet/Vlaardingese Vaart & 072980 & 443831 & 82134 & 439650 & 081987 & 439662 \\
\hline Nieuwe water & 089010 & 443487 & 73520 & $4 \mathrm{E}+06$ & 073331 & 443375 \\
\hline Nieuwe water & 088796 & 443356 & 73405 & 443331 & 072984 & 443640 \\
\hline Nieuwe water & 088622 & 443231 & 73139 & 443516 & 072792 & 444252 \\
\hline Nieuwe water & 088270 & 443010 & 72964 & 444019 & na & na \\
\hline Verversingskanaal & 078288 & 456246 & 78765 & 455858 & 078396 & 456134 \\
\hline Verversingskanaal & 078365 & 456205 & 78437 & 456088 & 078619 & 455878 \\
\hline Verversingskanaal & 078436 & 456087 & 78363 & 456205 & 078712 & 455717 \\
\hline Verversingskanaal & 078608 & 455900 & 78288 & 456247 & 078288 & 456247 \\
\hline
\end{tabular}


Wageningen Marine Research

T: $+31(0) 317480900$

E: marine-research@wur.nl

www.wur.nl/marine-research

Bezoekers adres:

- Ankerpark 27, 1781 AG Den Helder

- Korringaweg 7, 4401 NT Yerseke

- Haringkade 1, 1976 CP IJmuiden
Wageningen Marine Research levert met kennis, onafhankelijk wetenschappelijk onderzoek en advies een wezenlijke bijdrage aan een duurzamer, zorgvuldiger beheer, gebruik en bescherming van de natuurlijke rijkdommen in zee-, kust- en zoetwatergebieden. 